\title{
ANALISIS KEUNTUNGAN PENGRAJIN TAHU \\ BERDASARKAN CARA PEMBAYARAN DI KECAMATAN MALALAYANG, KOTA MANADO
}

\author{
Melkias Londo \\ Noortje M. Benu \\ Theodora M. Katiandagho
}

\begin{abstract}
ABSRACT
The objective of this research is to compare the benefits received of tofu before and after the increase in soybean prices in the payment system: payment system prior to production and after to production. This research was conducted in June to November 2016. The data used are primary data obtained through interviews of 10 (ten) respondents and secondary data obtained from the Malalayang Sub-district Office and the office of Service Industry at the Manado City. Analysis of the data used is the analysis of business advantage. The research result indicate that the increase in soybean prices resulted in a decrease of 14.28 percent profit amounted to -9.46 percent tofu for a businessman who uses a payment system prior to production and craftsmen who use the payment system after production decreased to -22.04 percent, the difference between the profit decline of tofu businessman that using a payment system before production and after production amounted to 12.58 percent. *jnkd*.
\end{abstract}

Keywords: profit, tofu, soybean, Manado City.

\begin{abstract}
ABSTRAK
Penelitian ini bertujuan untuk membandingkan keuntungan yang diterima pengrajin tahu sebelum dan sesudah kenaikan harga kedelai pada sistem pembayaran sebelum produksi dan sistem pembayaran setelah produksi. Penelitian ini dilaksanakan pada bulan Juni sampai bulan November 2016. Data yang digunakan adalah data primer yang diperoleh melalui wawancara kepada 10 (sepuluh) responden dan data sekunder diperoleh dari Kantor Kecamatan Malalayang dan Dinas Perindustrian, Kota Manado. Analisis data yang digunakan adalah analisis keuntungan usaha. Hasil penelitian ini menunjukkan bahwa kenaikan harga kedelai sebesar 14,28 persen mengakibatkan penurunan keuntungan pengrajin tahu sebesar $-9,46$ persen bagi pengrajin yang menggunakan sistem pembayaran sebelum produksi dan pengrajin yang menggunakan sistem pembayaran setelah produksi mengalami penurunan keuntungan -22,04 persen, degan selisih penurunan keuntungan antara pengrajin tahu yang menggunakan sistem pembayaran sebelum produksi dan setelah produksi adalah sebesar 12,58 persen.
\end{abstract}

Kata kunci: Keuntungan, Tahu, Kedelai, Kota Manado. 


\section{PENDAHULUAN}

\section{Latar Belakang}

Pertumbuhan penduduk, peningkatan kesadaran masyarakat akan pentingnya gizi, serta meningkatnya pertumbuhan industri olahan kedelai menyebabkan peningkatan permintaan kedelai. Sementara itu, disisi lain terjadi penurunan produksi kedelai yang disebabkan oleh penurunan areal luas panen dan rendahnya produktivitas. Kesenjangan antara peningkatan permintaan kedelai penurunan produksi kedelai dalam negeri menyebabkan terjadinya kekurangan stok kedelai diberbagai daerah di Indonesia, termasuk salah satunya adalah Sulawesi Utara. Kekurangan stok kedelai dalam negeri menyebabkan Indonesia mengalami ketergantungan yang tinggi terhadap kedelai Impor. (Sulut.BPS.go.id, 2015). Permintaan kedelai dalam negeri, lebih dari 90\% kedelai di Indonesia digunakan sebagai bahan pangan olahan yaitu sekitar $88 \%$ untuk tahu dan tempe, $10 \%$ untuk pangan olahan lain, dan $2 \%$ untuk benih. Total kebutuhan kedelai dalam negeri pertahun mencapai 2,4 juta ton, sementara produksi kedelai lokal hanya 900 ribu ton. Artinya, produksi kedelai dalam negeri belum mampu memenuhi kebutuhan untuk bahan baku pangan dan pakan. Ketidakmampuan produksi serta kualitas kedelai, untuk memenuhi kebutuhan dalam negeri telah menyebabkan Impor kedelai terus meningkat setiap tahunnya. Dalam kelompok tanaman pangan, kedelai merupakan komoditas terpenting ketiga setelah padi dan jagung, sehingga produksinya pun juga meningkat. (Sulut.BPS.go.i d, 2013). Pada tahun 2016 bulan Januari sampai bulan Desember perubahan harga bahan baku kedelai untuk pengrajin tahu di Malalayang Kota Manado dapat dilihat pada Tabel 1.

Tabel 1. Rata-rata Harga Bahan Baku Kedelai Impor untuk Pengrajin Tahu di Kecamatan Malalayang pada Bulan Januari - Desember Tahun 2016.

\begin{tabular}{|c|c|}
\hline Bulan & Harga (Rp.) \\
\hline Januari & 6.500 \\
\hline Februari & 6.800 \\
\hline Maret & 7.000 \\
\hline April & 7.500 \\
\hline Mei & 7.300 \\
\hline Juni & 7.000 \\
\hline Juli & 7.000 \\
\hline Agustus & 8.000 \\
\hline September & 7.600 \\
\hline Oktober & 8.000 \\
\hline November & 8.000 \\
\hline Desember & 8.500 \\
\hline Jumlah & 91.000 \\
\hline Rata-rata & $\mathbf{7 . 5 8 3 , 3 3}$ \\
\hline
\end{tabular}

Tabel 1 menunjukan bahwa pada bulan Januari tahun 2016 harga bahan baku kedelai Impor untuk pengrajin tahu di Malalayang Kota Manado masih berkisar Rp.6.500, bulan Februari sampai bulan Maret tahun 2016 mengalami kenaikan menjadi Rp.6.800 dan pada bulan April terus mengalami kenaikan menjadi Rp.7.500/kilo gram, pada bulan Mei turun menjadi Rp.7.300/kilo gram, pada bulan Juni dan Juli minggu pertama turun menjadi Rp.7.000/kilo gram, pada bulan Agustus minggu kedua sampai bulan September mingu pertama terjadi kenaikan menjadi Rp. 8.000/kilo gram. Pada bulan September minggu kedua harga bahan baku kedelai Impor kembali terjadi penurunan harga menjadi Rp.7.600/kilo gram. Pada bulan November kedelai impor terus mengalami kenaikan menjadi Rp.8.000/kilo gram sampai pada bulan Desember minggu pertama terus mengalami kenaikan menjadi Rp. 8.500/kilo gram. Sesuai dengan pengamatan pengrajin tahu, bahwa rata-rata terjadi kenaikan harga kedelai secara signifikan adalah biasanya terjadi mulai bulan Agustus sampai bulan Desember. Seperti halnya pada bulan Agustus dan september tahun 2015 harga kedelai naik dari Rp.6.000 menjadi Rp.9.000/kilo gram atau naik 94 persen (Aninomous, 2016).

Kenaikan harga kedelai yang fluktuatif, para pengrajin tahu memiliki strategi-strategi dalam memperoleh bahan baku kedelai agar tidak mengalami kerugian yang dapat berpengaruh pada proses produksi tahu, salah satunya adalah sistem pembayaran bahan baku kedelai sebelum produksi dan sesudah produksi. Dalam memperoleh bahan baku, sistem pembayaran bahan baku kedelai sebelum produksi atau sistem pembayaran langsung, pengrajin tahu akan mendapat potongan harga sebesar Rp.500/kilo gramnya dari agen sedangkan pengrajin tahu yang menggunakan sistem pembayaran setelah produksi tidak mendapat potongan harga, akan tetapi dapat membayar saat akan melakukan pemesanan ulang dan jika dalam jangka waktu pembayaran bahan baku terjadi penurunan atau kenaikan harga kedelai maka pengrajin tahu tetap membayar sesuai dengan harga saat melakukan pemesanan (tidak mengikuti harga), karena dalam hal ini antara pengrajin dan agen kedelai ada kesepakatan sistem kontrak. Bahan baku kedelai yang dipesan pengrajin tahu biasanya memesan untuk stok selama 2 minggu sampai satu bulan, tergantung dari pengrajin tahu. persiapan stok kedelai pengrajin sudah mempertimbangkan keadaan harga kedelai yang akan terjadi kedepan dalam hal ini pengrajin mengetahui kapan akan terjadi kenaikan harga 
kedelai. pengrajin tahu di Malalayang Kota Manado menggunakan kedelai impor dari Amerika nomor. 1 varietas Pagoda dengan berat 50 kilo gram/karung. Pengrajin lebih memilih kedelai impor Amerika karena ukuran lebih besar, warna putih, bersih dan lebih murah dibanding kedelai impor lainnya. Strategi sistem pembayaran bahan baku kedelai inilah yang digunakan oleh pengrajin tahu di Malalayang Kota Manado dalam mengatasi harga kedelai yang fluktuatif.

\section{Rumusan Masalah}

Berdasarkan Latar belakang tersebut maka inti permasalahan dalam penelitian ini adalah bagaimana perbandingan keutungan yang diperoleh pengrajin tahu sebelum dan sesudah kenaikan harga kedelai pada sistem pembayaran bahan baku kedelai sebelum produksi dan setelah produksi.

\section{Tujuan Penelitian}

Tujuan dari penelitian ini adalah untuk membandingkan perubahan keuntungan yang diterima pengrajin tahu sebelum dan sesudah kenaikan harga kedelai pada sistem pembayaran sebelum produksi dan sistem pembayaran setelah produksi pada harga kedelai yang berbeda.

\section{Manfaat Penelitian}

Penelitian ini diharapkan berguna bagi:

1. Memberikan kontribusi bagi mahasiswa yang akan melakukan penelitian yang sesuai.

2. Sebagai bahan masukan bagi pengrajin tahu untuk tetap mempertahankan strategi-strategi yang dugunakan dalam menghadapi harga kedelai yang tidak stabil (fluktuatif).

\section{METODE PENELITIAN}

\section{Lokasi dan Waktu Penelitian}

Penelitian ini dilaksanakan selama 6 bulan yaitu pada bulan Juni 2016 sampai bulan November 2016 dengan menetapkan lokasi penelitian di Kecamatan Malalayang Kota Manado.

\section{Metode Pengumpulan Data}

Jenis data yang akan digunakan dalam penelitian ini adalah data primer dan data sekunder. Data primer berupa profil pengrajin tahu dan keragaan usaha tahu sebelum dan setelah kenaikan harga kedelai diperoleh melalui survei dengan menggunakan teknik wawancara yang dipandu oleh kuisioner terstruktur. Sedangkan data sekunder diperoleh dari studi literatur yang bersumber dari kantor dinas perdagangan dan perindustrian Kota Manado, buku, dan skripsi/jurnal.

\section{Metode Pengambilan Sampel}

Responden yang dijadikan sampel adalah sebanyak 10 Pengrajin tahu dari 21 pengrajin tahu yang terdapat di daerah ini, 10 pengrajin tahu ini akan dibagi atas dua sistem pembayaran bahan baku yaitu pengrajin tahu yang menggunakan sistem pembayaran sebelum produksi dan sistem pembayaran sesudah produksi dalam memperoleh bahan baku kedelai. Pemilihan responden dilakukan dengan teknik secara sengaja (Purposive Sampling). Kriteria yang digunakan dalam pemilihan sampel adalah wawancara dengan menggunakan panduan kusioner yang telah disediakan dan memiliki lama usaha $>1$ tahun. Kriteria ini digunakan dengan pertimbangan untuk mengetahui perbandingan keuntungan yang diperoleh pengrajin tahu pada harga yang berbeda atau sistem pembayaran bahan baku kedelai yang berbeda pada minggu pertama bulan Juli dan minggu kedua bulan Agustus Tahun 2016. Harga produksi tahu dihitung dalam satuan ember dengan asumsi satu ember 250 potong tahu ukuran besar dan harga ampas tahu dihitung dalam satuan karung.

\section{Metode Pengumpulan Data}

Metode pengumpulan data dengan cara menyebarkan kuesioner terstruktur kepada responden. Wawancara kepada responden, dengan mengajukan pertanyan-pertanyaan yang terdiri dari:

1. Lama usaha : lamanya industri pengrajin tahu dalam memproduksi tahu yang sedang dijalani.

2. Alasan memilih usaha : merupakan suatu hal pendorong bagi pengrajin tahu dalam menjalankan usaha tahu.

3. Pengadaan bahan baku : proses memperoleh bahan baku kedelai dari agen.

4. Proses produksi tahu : suatu proses pembuatan tahu dari bahan baku kedelai.

5. Produksi : jumlah produksi tahu, dan ampas, yang dihasilkan sebelum dan sesudah kenaikan harga kedelai pada bulan Juli minggu pertama dan Agustus minggu kedua Tahun 2016 selama satu bulan. Tahu yang dihasilkan dihitung dalam ukuran ember per satu kali proses produksi, ampas tahu dihitung dalam satuan karung per satu kali proses produksi. 
6. Biaya produksi sebelum dan sesudah kenaikan harga kedelai pada sistem pembayaran bahan baku kedelai yang berbeda.

a. Biaya Tetap (Fixed Cost):

- Tenaga kerja (Rp) : biaya tenaga kerja yang digunakan dalam proses produksi tahu yang meliputi perendaman, penggilingan, pemasakan bubur kedelai, penyaringan, penggumpalan, dan percetakan. Penggunaan tenaga kerja diukur dalam satuan jam kerja bulan.

- Listrik (Rp) : biaya penggunaan energi listrik dalam membantu proses produksi tahu.

- Iuran pasar (Rp) : kontribusi wajib kepada pengelola pasar.

b. Biaya Tidak Tetap (Variable Cost):

- Kedelai (Rp) : biaya bahan baku utama yang dipakai produsen tahu untuk membuat tahu. Harga kedelai yang digunakan adalah harga kedelai yang berlaku disetiap produsen pada saat wawancara.

- Bahan penggumpal (Rp) : biaya bahan yang digunakan untuk tahu terbentuk.

- Solar (Rp) : biaya bahan bakar serbuk kayu yangb digunakan produsen tahu untuk memasak bubur kedelai dan dihitung dalam satuan karung/ ikat.

- Serbuk kayu dan kulit pala (Rp) : biaya bahan bakar serbuk kayu dan kulit pala yang digunakan untuk memasak bubur kedelai dan dihitung dalam satuan karung atau kilo gram.

- Transportasi : biaya pengangkutan hasil produk kedelai ke pasar untuk dijual ke konsumen.

c. Biaya tunai

Biaya tunai dari biaya tetap dapat berupa pajak tanah, sedangkan biaya tunai yang sifatnya variable antara lain berupa biaya untuk pemakaian bahan baku dan tenaga kerja luar keluarga (tenaga upahan).

d. Biaya tidak tunai

Biaya tidak tunai (diperhitungkan) meliputi biaya tetap seperti penyusutan alatalat dan lain-lain. Sedangkan biaya yang diperhitungkan dari biaya variable antara lain biaya untuk tenaga kerja keluarga. Biaya tidak tunai termasuk ke dalam biaya diperhitungkan, salah satunya adalah biaya penyusutan. Perhitungan biaya penyusutan tergantung kepada metode apa yang digunakan. Terdapat beberapa cara untuk mendapat nilai penyusutan.

Penyusutan peralatan, yaitu nilai penggunaan alat disebabkan oleh pemakaian alat selama proses produksi:

$$
D=\frac{\text { Haw-Hak }}{\text { WP }}
$$

Dimana : $\quad$ D $\quad=$ Penyusutan

$$
\begin{array}{ll}
\text { Haw } & \text { Nilai awal } \\
\text { Hak } & \text { Nilai akhir } \\
\text { WP } & =\text { Masa pakai }
\end{array}
$$

e. Perbandingan biaya produksi dan keuntungan yang diperoleh pengrajin tahu melalui sistem pembayaran langsung dan setelah produksi.

\section{Metode Analisis Data}

Analisis data yang digunakan dalam penelitian ini adalah analisis kuantitatif dan analisis kualitatif. Tahap analisis data yang dilakukan adalah tahap transfer data dalam bentuk tabulasi, editing serta pengolahan data dengan menggunakan paket perangkat lunak Microsoft Excel, kemudian dilanjutakn dengan tahap interpretasi data.

\section{Analisis Keuntungan Usaha}

Untuk menghitung pendapatan bersih usaha terlebih dahulu harus diketahui tingkat pendapatan total dan pengeluaran pada periode tertentu. Pendapatan total pengrajin tahu didekati dengan persamaan sebagai berikut (Boediono, 2000 : 105). $\mathbf{T R}=\mathbf{P} \times \mathbf{Q}$

Dimana :

TR = Total Revenue $($ Total Penerimaan pengrajin tahu)

$$
\begin{aligned}
& \mathrm{P}=\text { Price/ harga pokok tahu per ember } \\
& \mathrm{Q}=\text { Quantitas (jumlah produk tahu yang }
\end{aligned}
$$
dihasilkan)

Pendapatan bersih usaha tahu diperoleh dengan rumus sebagai berikut : (Boediono, 1993 : 106).

$\pi=\mathbf{T R}-\mathbf{T C}$

$\pi=$ Profit (keuntungan Pengrajin tahu)

$\mathrm{TR}=$ Total Revenue $($ Penerimaan pengrajin tahu)

$\mathrm{TC}=$ Total Cost (Biaya)

\section{HASIL DAN PEMBAHASAN}

\section{Gambaran Umum Kecamatan Malalayang}

Kecamatan Malalayang merupakan salah satu dari 9 Kecamatan yang ada di Kota Manado. Letak geografis Kecamatan Malalayang berada pada 0127'39" LU dan 12477'31" BT. Luas wilayah Kecamatan Malalayang sebesar 3024,75 km2. 
Kecamatan Malalayang terdiri dari 5 kelurahan. Tofografi Kecamatan Malalayang adalah dataran dan perbukitan.

\section{Jenis Kelamin}

\section{Karakteristik Pengrajin Tahu}

Berdasarkan survei yang dilakukan pada 10 responden pengrajin tahu dapat diketahui bahwa sebagian besar pemilik usaha tahu di Kecamatan Malalayang adalah laki-laki. Hal ini dapat terlihat bahwa jumlah responden pengrajin tahu lakilaki sebanyak 8 orang sedangkan pengrajin tahu perempuan hanya berjumlah 2 orang. Hal ini dikarenakan laki-laki memiliki peranan yang kuat sebagai kepala keluarga dan bertanggungjawab memberikan nafkah kepada keluarga sedangkan perempuan berperan sebagai seorang istri yang bertugas mengurus rumah tangga dan membantu suami dalam usaha yang membuat tahu. Responden pengrajin tahu berdasarkan jenis kelamin dapat dilihat pada Tabel 2.

Tabel 2. Jumlah dan Persentase Jenis Kelamin Responden

\begin{tabular}{|c|c|c|}
\hline Jenis Kelamin & $\begin{array}{c}\text { Jumlah } \\
\text { Pengrajin }\end{array}$ & Persentase (\%) \\
\hline Laki - laki & 8 & 80 \\
\hline Perempuan & 2 & 20 \\
\hline Total & 10 & 100 \\
\hline
\end{tabular}

Sumber: Diolah dari Data Primer, 2016

\section{Umur}

Berdasarkan umurnya, responden pengrajin tahu dikelompokkan menjadi 3 kelompok, yaitu kelompok umur 20-30 tahun, 31-40 tahun, 41-50 tahun dan $>50$ tahun jumlah dan presentasi dari masing-masing kelompok umur dapat dilihat pada Tabel 3.

Tabel 3. Jumlah dan Persentase Responden Menurut Kelompok Umur

\begin{tabular}{|c|c|c|}
\hline Kelompok Umur & $\begin{array}{c}\text { Jumlah } \\
\text { Pengrajin }\end{array}$ & Persentase (\%) \\
\hline $20-40$ & 2 & $20 \%$ \\
\hline $41-50$ & 6 & $60 \%$ \\
\hline$>50$ & 2 & $20 \%$ \\
\hline Total & 10 & $100 \%$ \\
\hline
\end{tabular}

Sumber: Diolah dari Data Primer, 2016

Dari Tabel 3 terlihat bahwa jumlah responden pengrajin tahu terbesar berada pada kelompok umur 41-50 tahun, yaitu sebanyak 6 responden (60 persen). Kemudian diikuti oleh kelompok umur 31-40 dan >50 tahun masingmasing memiliki jumlah responden yang sama sebanyak 4 responden (40 persen). Penyebaran responden yang hampir merata di setiap kelompok umur menunjukkan bahwa usaha tahu merupakan usaha yang digeluti oleh sebagian masyarakat Kecamatan Malalayang.

\section{Tingkat Pendidikan}

Secara umum tingkat pendidikan yang dimiliki oleh para pegarajin tahu masih sangat rendah. Hal ini dapat dilihat pada hasil survei bahwa pendidikan formal tertinggi yang dimiliki pengrajin adalah hanya sampai tingkat SMA yang berjumlah 2 orang (20 persen). Responden dengan tingkat pendidikan tamat SLTP berjumlah 5 orang (50 persen) dan yang tidak tamat SD berjumlah 3 orang (30 persen). Tingkat pendidikan dalam usaha membuat tahu tidak diperlukan pendidikan yang tinggi, tetapi cukup keterampilan membuat tahu yang diwariskan dari generasi sebelumnya, sehingga para orang tua tidak terlalu mementingkan pendidikan formal, disamping juga biaya pendidikan yang tidak murah. Sebaran responden berdasarkan tingkat pendidikan dapat dilihat pada Tabel 4.

Tabel 4. Jumlah dan Persentase Responden Menurut Tingkat Pendidikan

\begin{tabular}{|c|c|c|}
\hline $\begin{array}{c}\text { Tingkat } \\
\text { Pendidikan }\end{array}$ & $\begin{array}{c}\text { Jumlah } \\
\text { Pengrajin }\end{array}$ & Persentase (\%) \\
\hline Tidak Tamat SD & 3 & $30 \%$ \\
\hline Tamat SMP & 5 & $50 \%$ \\
\hline Tamat SMA & 2 & $20 \%$ \\
\hline Total & 10 & $100 \%$ \\
\hline
\end{tabular}

Sumber: Diolah dari Data Primer, 2016

\section{Lama Usaha}

Lama usaha setiap responden dalam menjalani usahanya sangat beragam. Responden yang telah menjalani usaha tahu antara 1 tahun sampai 5 tahun adalah sebanyak 3 orang ( 30 persen). Kelompok ini merupakan responden yang beralih dari profesi lain diantaranya penjual ikan, sayur dan baru menekuni usaha tahu karena melihat potensi pasar yang cukup baik dan tidak memerlukan keahlian tinggi. Responden yang telah menjalani usaha tahu antara 6 tahun sampai 10 tahun adalah sebanyak 2 orang ( 20 persen) dan responden yang telah menjalani usaha tahu 15 tahun adalah sebanyak 1 orang (10 persen) serta 4 orang (40) yang menjalani usaha lebih dari 15 tahun. Sebaran responden tahu berdasarkan lama usaha dapat dilihat pada Tabel 5. 
Tabel 5. Jumlah dan Persentase Responden Menurut Lamanya Usaha

\begin{tabular}{|c|c|c|}
\hline Lama Usaha & Jumlah Pengrajin & Persentase (\%) \\
\hline $1-5$ & 3 & 30 \\
\hline $6-10$ & 2 & 20 \\
\hline $11-15$ & 1 & 10 \\
\hline$>15$ & 4 & 40 \\
\hline Total & 10 & 100 \\
\hline
\end{tabular}

Sumber: Diolah dari Data Primer, 2016

\section{Alasan Memilih Usaha}

Alasan memilih usaha tahu sebagai sumber penghasilan keluarga bagi sebagian besar pengrajin tahu yaitu 4 responden (40 persen) di Kecamatan Malalayang adalah karena usaha tahu merupakan usaha turun menurun yang telah dijalankan dari generasi sebelumnya, responden yang alasan memilih karena banyak permintaan, modal kecil, serta karena proses produksi sederhana adalah masing-masing ada 2 orang (60 persen), sebaran responden berdasarkan alasan memilih usaha secara rinci dapat dilihat pada Tabel 6 .

Tabel 6. Jumlah dan Persentase Responden Menurut Alasan Memilih Usaha

\begin{tabular}{|c|c|c|}
\hline Alasan Memilih Usaha & $\begin{array}{c}\text { Jumlah } \\
\text { Pengrajin }\end{array}$ & $\begin{array}{c}\text { Persentase } \\
(\%)\end{array}$ \\
\hline Turun-Temurun & 3 & 30 \\
\hline Banyak Permintaan & 2 & 20 \\
\hline Modal Kecil & 1 & 10 \\
\hline $\begin{array}{c}\text { Proses Produksi } \\
\text { Sederhana }\end{array}$ & 4 & 40 \\
\hline Total & 10 & 100 \\
\hline
\end{tabular}

Sumber: Diolah dari Data Primer, 2016

\section{Tenaga Kerja}

Tenaga kerja yang digunakan oleh para pengrajin meliputi tenaga kerja keluarga dan tenaga kerja luar keluarga. Penggunaan tenaga kerja pengrajin tahu di Malalayang Kota Manado, kebanyakan adalah tenaga kerja dari keluarga sendiri. Sebaran responden tenaga kerja pengrajin tahu dapat dilihat pada Tabel 7 .

Tabel 7. Jumlah dan Persentase Responden Menurut Tenaga Kerja

\begin{tabular}{|c|c|c|}
\hline Bentuk tenaga kerja & $\begin{array}{c}\text { Jumlah } \\
\text { Pengrajin }\end{array}$ & $\begin{array}{c}\text { Persentase } \\
(\%)\end{array}$ \\
\hline Keluarga & 2 & 20 \\
\hline $\begin{array}{c}\text { Luar keluarga } \\
\text { Keluarga dan Luar } \\
\text { keluarga }\end{array}$ & 1 & 10 \\
\hline Total & 10 & 70 \\
\hline
\end{tabular}

Sumber: Diolah dari Data Primer, 2016
Responden yang menggunakan tenaga kerja keluarga ada sebanyak 2 responden (20 persen), responden yang menggunakan tenaga kerja luar keluarga terdapat 1 responden (10 persen) dan responden yang menggunakan tenaga kerja luar keluarga dan keluarga ada sebanyak 7 responden (70 persen). Jika dilihat dari keseluruhan tenaga kerja sebanyak 44 orang dari 10 responden rata-rata tenaga kerja keluarga sebanyak 24 orang dan 20 orang tenaga kerja luar keluarga. Kenaikan harga kedelai tidak berpengaruh terhadap tenaga kerja, karena tidak terdapat responden yang mengurangi tenaga kerja setelah adanya kenaikan harga kedelai.

\section{Pengadaan Bahan Baku dan Bahan Penolong}

Bahan baku yang digunakan pengrajin untuk memproduksi tahu adalah kedelai, ragi, air cuka, dan air. Bahan baku kedelai yang digunakan oleh para pengrajin adalah kedelai impor karena hanya kedelai impor yang dianggap baik untuk digunakan sebagai bahan baku untuk tahu, berhubung kedelai lokal yang biasa digunakan sebagai bahan baku tahu, tidak tahan sampai 24 jam sebelum dipasarkan (bau busuk). Para pengrajin mendapatkan kedelai dari agen yang sama. Pengrajin tahu membeli kedelai dengan dengan sistem yang berbeda tergantung modal yang dimiliki. Pengrajin yang memiliki modal besar biasa membayar lunas saat pembelian, pengrajin yang memiliki modal terbatas membayar separuh harga dan melunasi saat pembelian hari berikutnya, dan ada pula yang memesan bahan baku kedelai terlebih dahulu dan membayarnya pada saat pembelian berikutnya setelah tahu terjual. Kenaikan harga kedelai terhadap pengadaan bahan baku tidak memberikan dampak yang signifikan baik sebelum maupun sesudah kenaikan harga kedelai, kerena rata-rata para pengrajin biasanya tetap melakukan pembelian kedelai untuk stok satu sampai satu bulan. Hal ini dikarenakan pengrajin mendapat kepercayaan dari agen bahan baku kedelai yaitu berupa mitra kerja atau hubungan informal dalam penyediaan bahan baku kedelai impor. Sedangkan bahan penolong serbuk kayu dan kulit pala para pengrajin dapat membeli bahan bakar tersebut dari agen-agen kayu dan kulit pala yang tersebar di beberapa tempat, salah satunya dari Tondano sedangkan untuk solar para pengrajin biasanya membeli ditempat yang menyediakan solar.

\section{Cara Pengadaan Bahan Baku Kedelai}

Kedelai merupakan bahan baku utama pembuatan tahu dan memegang persentase terbesar dalam biaya produksi sehingga terjadinya kenaikan 
harga kedelai yang fluktuatif, menyebabkan para pengrajin tahu melakukan dua cara pembayaran untuk memperoleh bahan baku kedelai yaitu sistem pembayaran sebelum produksi dan sistem pembayaran setelah produksi. Pengadaan bahan baku kedelai dipesan sesuai dengan besarnya modal dari pengrajin tahu. Pengrajin yang menggunakan sistem pembayaran setelah produksi harus membayar terlebih dahulu kedelai yang dipesan sebelumnya, baru bisa melakukan pemesanan ulang bahan baku kedelai.

\section{Cara Pembayaran Bahan Baku Kedelai}

Bahan baku kedelai merupakan bahan utama untuk memproduksi tahu, bahan baku kedelai diperoleh dengan sistem pembayaran yang berbeda, sistem pembayaran bahan baku kedelai oleh pengrajin tahu di Malalayang Kota Manado dalam menghadapi harga kedelai yang fluktuatif melakukan dua sistem pembayaran dalam memperoleh bahan baku kedelai yaitu:

\section{A. Sistem Pembayaran Sebelum Produksi}

Sistem pembayaran sebelum produksi merupakan suatu strategi dari pengarajin tahu. sistem pembayaran ini dilakukan agar dapat mengurangi beban biaya bahan baku kedelai yang tidak stabil (fluktuatif), dalam memproduksi tahu pengrajin tahu yang melakukan pembayaran sebelum produksi mendapat potongan harga bahan baku kedelai setiap kilogramnya dari agen. Sebaran responden berdasarkan sistem pembayaran sebelum produksi dapat dilihat pada Tabel 8.

Sistem pembayaran bahan baku kedelai pada pengrajin tahu terdapat 5 responden $(50 \%)$ melakukan pemesanan kedelai dengan sistem pembayaran sebelum produksi saat pengrajin mempersiapkan stok bahan baku kedelai selama satu minggu sampai satu bulan, tergantung modal yang ada. Pemesanan bahan baku kedelai dengan sistem ini, pengrajin akan mendapat pemotongan harga dari agen kedelai sebesar Rp. 500/ kilo gram (7,14 persen) dari harga Rp. 8.000 menjadi Rp. 7.500/ kilo gram. Jadi dengan menggunakan sistem pembayaran sebelum produksi pengrajin tahu dapat menekan biaya untuk bahan baku kedelai sebesar 7,14 persen/ kilo gramnya. Kedelai yang diperoleh pengrajin dari agen adalah merupakan kedelai impor dari Amerika-Serikat, karena menurut pengrajin kedelai impor dari Amerika lebih berkualitas dalam hal bentuk, bersih, ukuran besar, warna putih dibanding kedelai impor dari negara-negara lain dan kedelai lokal. Sehingga pengrajin memiliki alasan yang kuat lebih memilih kedelai impor Amerika saat pemesanan bahan baku kedelai. Sistem ini digunakan untuk mengatasi harga kedelai yang tidak stabil (fluktuatif).

\section{B. Sistem Pembayaran Setelah Produksi}

Sistem pembayaran bahan baku kedelai setelah produksi merupakan strategi dari pengrajin tahu, dalam hal ini untuk menekan besarnya biaya bahan baku kedelai yang tidak stabil (fluktuatif), pengrajin yang menggunakan strategi ini adalah pengrajin yang memiliki keterbatasan modal untuk pemesanan bahan baku kedelai. Sebaran responden berdasarkan sistem pembayaran sebelum produksi dapat dilihat pada Tabel 9.

Sistem pembayaran setelah produksi terdapat 5 responden $(50 \%)$ melakukan pemesanan bahan baku kedelai, pemesanan bahan baku kedelai dengan sistem ini pengrajin tahu tidak mendapat pemotongan harga kedelai oleh agen dari harga yang sebenarnya, dapat dilihat pada Tabel 9 bahwa pengrajin akan tetap membayar biaya kenaikan harga kedelai sebesar Rp. $1.000 /$ kilo gram atau 14,28 persen/kilo gram. Namun dengan penggunaan sistem pembayaran ini, pengrajin dapat mengumpulkan modal untuk membayar biaya bahan baku yang dipesan sebelumnya dan adanya kesepakatan kontrak biaya bahan baku kedelai. Maka jika dalam jangka waktu pembayaran bahan baku yang dipesan sebelumnya terjadi penurunan harga atau kenaikan harga maka pengrajin tahu tetap membayar sesuai harga kedelai saat memesan bahan baku kedelai sebelumnya.

\section{Proses Produksi Tahu}

Proses produksi tahu dalam satu minggu, pengrajin tahu memproduksi tahu setiap harinya tanpa libur. Rata- rata penggunaan bahan baku kedelai dari keseluruhan responden setiap harinya adalah 145 kilo gram. Sebelum dan sesudah kenaikan harga kedelai pada bulan Juli minggu pertama dan bulan Agustus minggu kedua tahun 2016 pengrajin tahu tetap memproduksi tahu setiap hari, karena melihat permintaan produk tahu yang selalu ada setiap hari dan jika mereka tidak memproduksi tahu satu hari saja maka akan mengurangi pendapatan pengrajin tahu dan jika dilihat dari hasil penelitian bahwa semua pengrajin tahu merupakan penganut agama Muslim. Sebelum dan sesudah kenaikan harga kedelai pada bulan Juli minggu pertama dan bulan Agustus minggu kedua tahun 2016 para pengrajin tahu tidak mengurangi volume produksi tahu di kecamatan Malalayang Kota Manado tetapi para pengrajin tahu tetap melakukan dua sistem pembayaran untuk memperoleh bahan baku kedelai yaitu sitem pembayaran sebelum produksi dan sistem pembayaran setelah produksi. Pengrajin tidak merubah ukuran tahu, menaikkan harga, pengurangan penggunaan bahan baku kedelai dan pengurangan tenaga kerja. Jika dilakukan pengurangan ukuran maka akan bertambah kecil karena biasanya dari pabrik ke pengecer mengurangi ukuran tahu sebelum dijual dipasar. Pengrajin tahu biasanya mengurangi 
produksi tahu pada saat harga ikan turun karena biasanya pengrajin mengalami kerugian berhubung rata-rata tahu tidak terjual habis sama seperti biasanya penyebabnya konsumen lebih memilih ikan. Pengrajin tahu biasanya merubah harga tahu per ember jika harga kedelai mengalami kenaikan harga diatas Rp. 1.000/kilogram. Pengrajin tahu di Kecamatan Malalayang tergolong sebagai industri rumah tangga dengan proses produksi yang masih sangat sederhana, peralatan yang digunakan juga masih sederhana atau tradisional. Peralatan yang digunakan antara lain mesin penggiling kedelai, drum, kain tahu, papan cetakan, saringan, bujur, bak perebusan, gayung, pisau, mistar dan ember. Proses produksi tahu di Kecamatan Malalayang meliputi perendaman kedelai, penggilingan, pemasakan, penyaringan, penggumpalan, pencetakan, pemotongan, pematangan tahu.

\section{Waktu Produksi}

Rata-rata pengrajin membutuhkan waktu sekitar 10,7 jam untuk mengolah $70 \mathrm{~kg}$ kedelai menjadi tahu setiap harinya, tergantung dari besarnya bak perebusan. Pengrajin tahu mulai bekerja pada pagi hari sekitar pukul 06:00 sampai pukul 16:00, mulai dari menggiling kedelai sampai merebus tahu yang sudah jadi. Langkah awal yang dilakukan para pengrajin untuk membuat tahu adalah dengan melakukan perendaman kedelai selama kurang lebih 8 jam di dalam ember. Perendaman biasanya dilakukan pada saat malam hari sehingga siap untuk digiling pada pagi harinya. Kedelai yang telah direndam kemudian digiling dengan menggunakan mesin penggiling kedelai yang berbahan bakar solar. Dalam hal ini, responden yang memiliki mesin penggiling kedelai terdapat sebanyak 9 orang (90 persen) dan sisanya 1 orang (10 persen) tidak memiliki mesin sendiri sehingga untuk menggiling kedelainya mereka menyewa mesin tetangga dengan membayar sewa. Biaya sewa penggilingan untuk setiap $40 \mathrm{~kg}$ adalah Rp. 40.000 dapat dilihat pada Tabel 10. Kedelai yang telah digiling kemudian dimasukkan kedalam bak perebusan untuk dimasak. Bahan bakar yang digunakan oleh para pengrajin untuk memasak bubur kedelai adalah kulit pala dan serbuk kayu (disesuaikan dengan ketersediaan bahan bakar yang ada). Bubur kedelai yang telah dimasak disaring dengan menggunakan saringan. Sari kedelai kemudian digumpalkan dengan menggunakan cuka. Dalam memproduksi tahu, setiap 50 kilogram kedelai menghasilkan 10 ember tahu (ukuran besar).

Tabel 8. Harga Kedelai dengan Sistem Pembayaran Sebelum Produksi

\begin{tabular}{|c|c|c|c|}
\hline Res. & Harga Kedelai $(\mathrm{Kg})$ Sebelum Kenaikan $(\%)$ & Harga Kedelai $(\mathrm{Kg})$ Sesudah Kenaikan $(\%)$ & Perubahan $(\%)$ \\
\hline 1 & 7000 & 7500 & 7,14 \\
\hline 2 & 7000 & 7500 & 7,14 \\
\hline 3 & 7000 & 7500 & 7,14 \\
\hline 4 & 7000 & 7500 & 7,14 \\
\hline 5 & 7000 & 7500 & 7,14 \\
\hline Jumlah & 35.000 & 37.500 & 35,7 \\
\hline Rata-rata & 7.000 & 7.500 & 7,14 \\
\hline
\end{tabular}

Sumber: Diolah dari Data Primer, 2016

Tabel 9. Harga Kedelai dengan Sistem Bayar Setelah Produksi

\begin{tabular}{|c|c|c|c|}
\hline Res. & Harga Kedelai (Kg) Sebelum Kenaikan (\%) & Harga Kedelai (Kg) Sesudah Kenaikan (\%) & Perubahan $(\%)$ \\
\hline 6 & 7000 & 8000 & 7,14 \\
\hline 7 & 7000 & 8000 & 14,28 \\
\hline 8 & 7000 & 8000 & 14,28 \\
\hline 9 & 7000 & 8000 & 14,28 \\
\hline 10 & 7000 & 8000 & 14,28 \\
\hline Jumlah & 35.000 & 40.000 & 71,4 \\
\hline Rata-rata & 7.000 & 8.000 & 14,28 \\
\hline
\end{tabular}

Sumber: Diolah dari Data Primer, 2016

Tabel 10. Jumlah dan Persentase Responden Pengrajin Tahu Menurut Kepemilikan Mesin Penggiling

\begin{tabular}{|c|c|c|}
\hline Kepemilikan Mesin Giling & Jumlah (orang) & Persentase (\%) \\
\hline Memiliki & 9 & 90 \\
\hline Tidak Memiliki & 1 & 10 \\
\hline Jumlah & 10 & 100 \\
\hline Rata-rata & 7.000 & 8.000 \\
\hline
\end{tabular}

Sumber: Diolah dari Data Primer, 2016 


\section{Penggunaan Bahan Baku Kedelai}

Bahan baku kedelai merupakan bahan utama yang paling besar dalam pengeluaran biaya untuk produksi. Jumlah pemakaian bahan baku kedelai untuk pengrajin tahu sangat bervariatif, rata-rata dari 5 pengrajin tahu yang menggunakan sistem pembayaran sebelum produksi adalah industri yang cukup besar. Penggunaan input untuk produksi tahu dapat dilihat pada Tabel 11. Pengrajin tahu yang menggunakan sistem pembayaran sebelum produksi baik sebelum maupun sesudah kenaikan harga kedelai dari 5 pengrajin tahu per hari membutuhkan 2.300 kilo gram bahan baku kedelai dan 7.700 kilo gram bahan baku kedelai per bulannnya.

Kemudian penggunaan bahan baku kedelai setiap harinya dari 5 pengrajin tahu adalah rata-rata 220 kilo gram dan rata-rata per bulannya adalah 1.540 kilo gram. Sebelum kenaikan maupun sesudah kenaikan harga kedelai tidak ada perubahan penggunaan bahan baku karena jumlah volume penggunaan bahan baku kedelai tetap sama, tanpa ada pengurangan bahan baku kedelai. Pengrajin tahu dalam memperoleh bahan baku kedelai dengan sistem pembayaran sesudah produksi dapat dilihat pada Tabel 12 dibawah ini.Pengrajin tahu yang menggunakan sistem pembayaran sesudah produksi baik sebelum maupun sesudah kenaikan harga kedelai dari 5 pengrajin tahu per hari membutuhkan 675 kilo gram bahan baku kedelai dan 4.165 kilo gram bahan baku kedelai per bulannnya.

Kemudian penggunaan bahan baku kedelai setiap harinya dari masing-masing 5 pengrajin tahu yang menggunakan sistem pembayaran sesudah produksi adalah rata-rata 135 kilo gram dan rata-rata per bulannya adalah 833 kilo gram. Jika dilihat dari pengrajin yang menggunakan sistem pembayaran sebelum produksi maupun sistem pembayaran sesudah produksi, penggunaan bahan baku kedelai baik sebelum kenaikan maupun sesudah kenaikan harga bahan baku kedelai, selisih penggunaan bahan baku kedelai adalah 1.625 kilo gram per hari dan 3.605 kilo gram per bulannya.

\section{Produksi Tahu}

Produksi tahu merupakan hasil output dari usaha tahu, sedangkan ampas tahu merupakan sisa dari kedelai yang telah digiling untuk pembuatan tahu. produksi tahu dan produksi ampas tahu/minggunya dapat dilihat pada Tabel 13. dibawah ini. Pada Tabel 13 menunjukkan hasil produksi tahu dan ampas tahu 5 pengrajin tahu $(50 \%)$ yang menggunakan sistem pembayaran sebelum produksi.

Baik sebelum maupun sesudah kenaikan bahan baku kedelai tidak menunjukkan adanya perubahan penurunan maupun peningkatan hasil produksi tahu dan ampas tahu karena pengrajin tahu tidak mengubah volume penggunaan bahan baku kedelai. hasil produksi tahu yang palin besar ditunjukkan oleh responden dua dan tiga yaitu 336 ember/minggu, kemudian responden dua 280 ember/minggu dan responden satu dan lima 210 ember/minggu. Begitupun dengan hasil dari ampas tahu yang ada.

Pada Tabel 14 menunjukkan hasil produksi tahu dari pengrajin yang menggunakan sistem pembayaran sesudah produksi. jika dilihat dari Tabel 15 yaitu pengrajin yang menggunakan sistem pembayaran sebelum produksi, selisih hasil produksi tahu sangat berbebedah jauh karena volume penggunaan bahan baku kedelai anatara sistem pembayaran sebelum produksi dan sistem pembayaran sesudah produksi sangat jauh berbedah. Pada Tabel 14 menunjukkan besarnya hasil produksi tahu dan ampas tahu dari pengrajin yang menggunakan sistem pembayaran sesudah produksi. Jika dilihat dari kelima pengrajin tahu yang ada hasil produksinya sangat bervariatif.

Hasil produksi terbesar ditunjukkan oleh responden enam yaitu 210 ember/minggu, responden tujuh 168 ember/minggu, responden delapan 154 ember/minggu, responden sembilan 195 ember/minggu dan responden sepuluh 105 ember/minggu dan ampas tahu responden enam $21 \mathrm{karung} / \mathrm{minggu}$, responden tujuh.delapan dan sembilan masing-masing 18 ember/minggu dan responden sepuluh $10 \mathrm{karung} / \mathrm{minggu}$.

\section{Biaya Produksi}

Pengeluaran pengrajin tahu adalah semua biaya yang dikeluarkan selama proses produksi. Komponen biaya pengrajin tahu terdiri dari biaya tetap dan biaya tidak tetap. Besarnya biaya produksi pengrajin tahu selama satu minggu dapat dilihat pada Tabel 15. 
Tabel 11. Volume Penggunaan Bahan Baku Kedelai dengan Sistem Pembayaran Sebelum Produksi

\begin{tabular}{|c|c|c|c|c|}
\hline \multirow{2}{*}{ Resp. } & \multicolumn{2}{|c|}{ Sebelum } & \multicolumn{2}{c|}{ Persentase (\%) } \\
\cline { 2 - 5 } & $(\mathrm{Kg} / \mathrm{Hari})$ & $(\mathrm{Kg} / \mathrm{Minggu})$ & 2.300 & 7.700 \\
\hline 1 & 150 & 1050 & 2.300 & 7.700 \\
\hline 2 & 250 & 1750 & 2.300 & 7.700 \\
\hline 3 & 250 & 1750 & 2.300 & 7.700 \\
\hline 4 & 200 & 1400 & 2.300 & 7.700 \\
\hline 5 & 150 & 1050 & 2.300 & 7.700 \\
\hline Jumlah & 2.300 & 7.700 & 220 & 1.540 \\
\hline Rata-rata & 220 & 1.540 & & \\
\hline
\end{tabular}

Sumber: Diolah dari Data Primer, 2016

Tabel 12. Volume Penggunaan Bahan Baku Kedelai dengan Sistem Pembayaran Sesudah Produksi

\begin{tabular}{|c|c|c|c|c|}
\hline \multirow{2}{*}{ Resp. } & \multicolumn{2}{|c|}{ Sebelum } & \multicolumn{2}{c|}{ Persentase (\%) } \\
\cline { 2 - 5 } & $(\mathrm{Kg} / \mathrm{Hari})$ & $(\mathrm{Kg} / \mathrm{King} / \mathrm{Mg} / \mathrm{Hari})$ & 150 & 1050 \\
\hline 6 & 150 & 1050 & 120 & 840 \\
\hline 7 & 120 & 840 & 110 & 110 \\
\hline 8 & 110 & 770 & 140 & 140 \\
\hline 9 & 140 & 980 & 75 & 525 \\
\hline 10 & 75 & 525 & 675 & 4.165 \\
\hline Jumlah & 675 & 4.165 & 135 & 833 \\
\hline
\end{tabular}

Sumber: Diolah dari Data Primer, 2016

Tabel 13. Volume Produksi Tahu dan Ampas Tahu per Minggu pada Sistem Pembayaran Sebelum Produksi

\begin{tabular}{|c|c|c|c|c|}
\hline \multirow[t]{2}{*}{ Resp. } & \multicolumn{2}{|c|}{ Tahu } & \multicolumn{2}{|c|}{ Ampas Tahu } \\
\hline & $\begin{array}{c}\text { Sebelum } \\
\text { (ember/minggu) }\end{array}$ & $\begin{array}{c}\text { Sesudah } \\
\text { (ember/minggu) }\end{array}$ & $\begin{array}{c}\text { Sebelum } \\
\text { (karung/minngu) }\end{array}$ & $\begin{array}{c}\text { Sesudah } \\
\text { (karung/minggu) }\end{array}$ \\
\hline 1 & 210 & 210 & 21 & 21 \\
\hline 2 & 336 & 336 & 35 & 35 \\
\hline 3 & 336 & 336 & 35 & 35 \\
\hline 4 & 280 & 280 & 28 & 28 \\
\hline 5 & 210 & 210 & 21 & 21 \\
\hline Jumlah & 1498 & 1498 & 150 & 150 \\
\hline
\end{tabular}

Sumber: Diolah dari Data Primer, 2016

Tabel 14. Volume Produksi Tahu dan Ampas Tahu per Minggu pada Sistem Pembayaran Sesudah Produksi

\begin{tabular}{|c|c|c|c|c|}
\hline \multirow{2}{*}{ Resp. } & \multicolumn{2}{|c|}{ Tahu } & \multicolumn{2}{c|}{ Ampas Tahu } \\
\cline { 2 - 5 } & $\begin{array}{c}\text { Sebelum } \\
\text { (ember/minggu }\end{array}$ & $\begin{array}{c}\text { Sesudah } \\
\text { (ember/minggu) }\end{array}$ & $\begin{array}{c}\text { Sebelum } \\
\text { (karung/minngu) }\end{array}$ & 21 \\
\hline 6 & 210 & 210 & 18 & 18 \\
\hline 7 & 168 & 168 & 18 & 18 \\
\hline 8 & 154 & 154 & 18 & 18 \\
\hline 9 & 195 & 195 & 10 & 150 \\
\hline Jumlah & 105 & 105 & 150 & 10 \\
\hline
\end{tabular}

Sumber: Diolah dari Data Primer, 2016

Tabel 15. Biaya Produksi dengan Sistem Pembayaran Sebelum Produksi

\begin{tabular}{|c|c|c|c|c|}
\hline Resp. & Sebelum (Rp) & Sesudah (Rp) & Selisih (Rp) & Perubahan (\%) \\
\hline 1 & $9.536 .243,6$ & $10.271 .244,6$ & $-734.900,4$ & $-7,70$ \\
\hline 2 & $15.269 .850,79$ & $16.144 .850,79$ & -875.000 & $-5,70$ \\
\hline 3 & $16.228 .601,13$ & $17.104 .101,13$ & -875.000 & $-5,39$ \\
\hline 4 & $14.408 .461,9$ & $15.108 .461,9$ & -700.000 & $-4,86$ \\
\hline 5 & $10.501 .909,31$ & $11.001 .909,31$ & -500.000 & $-4,76$ \\
\hline Jumlah & $65.945 .066,73$ & $69.630 .567,73$ & $-3.684 .900,40$ & $-28,41$ \\
\hline
\end{tabular}

Sumber: Diolah dari Data Primer, 2016 
Perubahan biaya pengeluaran untuk bahan baku kedelai, pengrajin tahu yang menggunakan sistem pembayaran sebelum produksi dari kenaikan harga kedelai 14,28 persen, pengrajin tahu mengalami kenaikan rata-rata biaya bahan baku kedelai sebesar 7,14 persen. Pada responden satu mengalami kenaikan biaya produksi untuk pengrajin tahu sebesar $-7,70$ persen, responden dua $-5,70$ persen, responden tiga 5,39 persen, responden empat $-4,86$ persen dan responden lima $-4,76$ persen. Jumlah perubahan kenaikan biaya dari 5 pengrajin tahu adalah 28,41 persen. Perubahan biaya produksi untuk pengrajin tahu yang menggunakan sistem pembayaran sesudah produksi dalam memperoleh bahan baku kedelai dapat dilihat pada Tabel 16. Perubahan biaya pengeluaran untuk bahan baku kedelai, pengrajin tahu yang menggunakan sistem pembayaran sebelum produksi dari kenaikan harga kedelai 14,28 persen, pengrajin tahu tidak mendapat pengurangan biaya dari agen kedelai, maka rata-rata biaya produksi yang harus ditanggung pengrajin tahu pada kenaiakan harga kedelai adalah 14,28 persen. Pada Tabel 16 dapat dilihat perubahan biaya dari setiap responden. Responden satu mengalami kenaikan biaya produksi untuk pengrajin tahu sebesar $-8,88$ persen, responden dua $-16,47$ persen, responden tiga $-8,85$ persen, responden empat $-9,56$ persen dan responden lima $-8,87$ persen. Jumlah perubahan kenaikan biaya dari 5 pengrajin tahu adalah $-55,07$ persen.

\section{Penerimaan dan Pendapatan}

Pendapatan pengrajin tahu adalah selisih antara total penerimaan dan total pengeluaran/biaya. Penerimaan pengrajin tahu merupakan perkalian antara total produk yang dihasilkan dalam satu bulan produksi di kalikan dengan harga jual. Penerimaan pengrajin tahu berdasarkan sistem pembayaran bahan baku dapat dilihat pada Tabel 17. Berdasarkan Tabel 17, dapat dilihat bahwa penerimaan pengrajin tahu yang menggunakan sistem pembayaran sebelum produksi, baik produksi tahu maupun ampas tahu tidak mengalami perubahan penerimaan karena pada kenaikan harga kedelai pengrajin tahu tidak menaikkan harga tahu dan mengurangi atau menaikkan volume produksi tahu. Menurut pengrajin tahu bahwa harga tahu akan dinaikkan/embernya pada saat harga kedelai mengalami kenaikan harga diatas Rp. 1.000/kilo gram. Jika dilihat pada Tabel 17 menunjukkan bahwa pendapatan pengrajin tahu yang menggunakan sistem pembayaran sebelum produksi (sesudah dan sebelum kenaikan harga kedelai), baik tahu maupun ampas tahu masing-masing pengrajin tahu tidak mengalami perubahan penerimaan yang diperoleh.

Pada Tabel 18 diatas pengarajin tahu yang menggunakan sistem pembayaran sesudah produksi, penerimaan pengrajin tahu baik hasil produksi tahu maupun ampas tahu tidak mengalami perubahan karena pengrajin tahu tidak menaikkan harga tahu dan perubahan volume produksi tahu. Menurut pengrajin tahu bahwa perubahan harga tahu setiap embernya akan dirubah ketika harga kedelai mengalami kenaikan diatas Rp. 1000/kilo gramnya. Jika dilihat pada Tabel 17, bahwa penerimaan pengrajin tahu yang menggunakan sistem pembayaran setelah produksi dalam memperoleh bahan baku kedelai baik penerimaan hasil produksi tahu maupun ampas tahu pengarajin tidak mengalami perubahan penerimaan.

\section{Analisis Keuntungan Pengrajin Tahu}

Keuntungan pengrajin tahu merupakan hasil dari total pendapatan usaha pengrajin tahu dikurangi dengan total biaya usaha pengrajin tahu. keuntungan pengrajin tahu dapat dilihat pada Tabel 19. Kenaikan harga kedelai untuk pengadaan bahan baku kedelai dengan menggunakan sistem pembayaran sebelum produksi, keuntungan pengrajin tahu mengalami penurunan. Sistem pembayaran sebelum produksi merupakan salah satu cara pengrajin tahu dalam menghindari kenaikan harga kedelai (fluktuatif) yang dapat berpengaruh pada keuntungan pengrajin tahu. Kenaikan harga kedelai dari kelima pengrajin tahu mengalami penurunan kentungan dapat dilihat pada Tabel 19 responden satu mengalami penurunan keuntungan sebesar $-10,90$ persen, responden kedua 7,89 persen, responden ketiga $-8,65$ persen, responden ke-empat -8,76 persen dan responden ke-lima mengalami penurunan keuntungan sebesar -7,68 persen. Jumlah perubahan penurunan keuntungan dari pengarajin yang menggunakan sistem pembayaran sebelum produksi dalam memperoleh bahan baku kedelai adalah -9,46 persen.Kenaikan harga kedelai 14,28 persen, dengan menggunakan sistem bayar langsung dapat mengurangi biaya bahan baku kedelai sebesar Rp. 500/kilo gramnya.

Tabel 20 menunjukan bahwa sistem pembayaran setelah produksi merupakan suatu alasan pengrajin tahu karena keterbatasan modal untuk membayar bahan baku kedelai. Kenaikan harga kedelai 14,28 persen, pengrajin tahu harus membayar biaya bahan baku kedelai tanpa pemotongan harga dari agen kedelai. Sistem pembayaran setelah produksi pengrajin tahu mengalami penurunan keuntungan dapat dilihat pada Tabel 20 responden satu mengalami penurunan keuntungan sebesar -20,25 persen, responden kedua 20,98 persen, responden ketiga $-20,22$ persen, responden ke-empat $-16,82$ persen dan responden ke-lima mengalami penurnan keuntungan $-19,46$ persen. Jumlah perubahan penurunan keuntungan dari pengarajin yang menggunakan sistem pembayaran setelah produksi dalam memperoleh bahan baku kedelai adalah -22,04 persen. Penggunaan sistem ini pengrajin dapat mengumpulkan modal untuk membayar bahan baku kedelai yang dipesan sebelumnya. Perbandingan keuntungan pengrajin tahu berdasarkan system pembayaran bahan baku kedelai dapat dilihat pada Tabel 21. 
Tabel 16. Biaya Produksi dengan Sistem Pembayaran Sesudah Produksi

\begin{tabular}{|c|c|c|c|c|}
\hline Resp. & Sebelum $(\mathrm{Rp})$ & Sesudah (Rp) & Selisih (Rp) & Perubahan (\%) \\
\hline 6 & $11.824 .993,64$ & $12.874 .993,64$ & $-734.900,4$ & $-8,88$ \\
\hline 7 & $7.646 .132,54$ & $8.906 .132,54$ & -1.260 .000 & $-16,47$ \\
\hline 8 & $8.692 .632,63$ & $9.462 .812,63$ & -770.000 & $-8,85$ \\
\hline 9 & $10.245 .419,11$ & $11.225 .419,11$ & -980.000 & $-9,56$ \\
\hline 10 & $5.912 .688,09$ & $6.437 .688,09$ & -525.000 & $-8,87$ \\
\hline Jumlah & $44.321 .866,01$ & $48.897 .046,01$ & -4.585 .000 & $-55,07$ \\
\hline
\end{tabular}

Sumber: Diolah dari Data Primer, 2016

Tabel 17. Penerimaan Pengrajin Tahu pada Kenaikan Harga Kedelai dengan Sistem Pembayaran Sebelum Produksi dan Setelah Produksi

\begin{tabular}{|c|c|c|c|c|}
\hline \multirow{2}{*}{ Resp. } & \multicolumn{2}{|c|}{ Tahu } & \multicolumn{2}{c|}{ Ampas Tahu } \\
\cline { 2 - 5 } & Sebelum (Rp) & Sesudah (Rp) & Sebelum (Rp) & Sesudah (Rp) \\
\hline 1 & 16.800 .000 & 16.800 .000 & 210.000 & 350.000 \\
\hline 2 & 26.880 .000 & 26.880 .000 & 350.000 & 350.000 \\
\hline 3 & 26.880 .000 & 26.880 .000 & 280.000 & 280.000 \\
\hline 4 & 22.400 .000 & 22.400 .000 & 210.000 & 210.000 \\
\hline 5 & 16.800 .000 & 16.800 .000 & 1.400 .00 & 1.400 .00 \\
\hline
\end{tabular}

Sumber: Diolah dari Data Primer, 2016

Tabel 18. Penerimaan Pengrajin Tahu pada Kenaikan Harga Kedelai dengan Sistem Pembayaran Sesudah Produksi dan Setelah Produksi

\begin{tabular}{|c|c|c|c|c|}
\hline \multirow{2}{*}{ Resp. } & \multicolumn{2}{|c|}{ Tahu } & \multicolumn{2}{c|}{ Ampas Tahu } \\
\cline { 2 - 4 } & Sebelum (Rp) & Sesudah (Rp) & Sebelum (Rp) & Sesudah (Rp) \\
\hline 6 & 16.800 .000 & 16.800 .000 & 210.000 & 18.000 \\
\hline 7 & 13.440 .000 & 13.440 .000 & 180.000 & 180.000 \\
\hline 8 & 12.320 .000 & 12.320 .000 & 180.000 & 180.000 \\
\hline 9 & 15.680 .000 & 15.680 .000 & 180.000 & 100.000 \\
\hline 10 & 8.400 .000 & 8.400 .000 & 100.000 & 850.000 \\
\hline Jumlah & 66.640 .000 & 66.640 .000 & 850.000 & \\
\hline
\end{tabular}

Sumber: Diolah dari Data Primer, 2016

Tabel 19. Perubahan Keuntungan Pengrajin Tahu pada Kenaikan Harga Kedelai dengan Sistem Pembayaran Sebelum Produksi

\begin{tabular}{|c|c|c|c|c|}
\hline \multirow{2}{*}{ Resp. } & Sebelum & Setelah & \multicolumn{2}{|c|}{ Perubahan $(\%)$} \\
\cline { 2 - 3 } & Jumlah (Rp/Minggu) & Jumlah (Rp/Minggu) & Selisih (Rp) & $-10,90$ \\
\hline 1 & $7.473 .756,4$ & $6.738 .756,4$ & 735.000 & $-7,89$ \\
\hline 2 & $11.001 .398,87$ & $11.085 .149,21$ & 875.000 & $-8,65$ \\
\hline 3 & $7.991 .538,1$ & $10.125 .898,87$ & 875.000 & $-8,76$ \\
\hline 4 & $10.245 .419,11$ & $7.291 .538,1$ & 700.000 & $-7,68$ \\
\hline 5 & $6.508 .091,69$ & $6.008 .091,69$ & 500.000 & $-9,46$ \\
\hline
\end{tabular}

Tabel 20. Perubahan Keuntungan Pengrajin Tahu pada Kenaikan Harga Kedelai dengan Sistem Bayar Setelah Produksi

\begin{tabular}{|c|c|c|c|c|}
\hline \multirow{2}{*}{ Resp. } & Sebelum & Setelah & \multirow{2}{*}{ Perubahan (\%) } \\
\cline { 2 - 3 } & Jumlah (Rp/Minggu) & Jumlah (Rp/Minggu) & Selisih (Rp) & $-20,25$ \\
\hline 6 & $5.185 .007,36$ & $4.135 .007,36$ & -1.050 .000 & $-20,98$ \\
\hline 7 & $5.185 .007,36$ & $4.135 .007,36$ & -1.260 .000 & $-20,22$ \\
\hline 8 & $3.807 .367,47$ & $3.037 .367,47$ & -770.000 & $-16,82$ \\
\hline 9 & $5.824 .581,89$ & $4.844 .581,89$ & -980.000 & $-19,46$ \\
\hline 10 & $2.697 .312,91$ & $2.172 .312,91$ & -525.000 & $-22,04$ \\
\hline Jumlah & $26.548 .134,51$ & $21.753 .134,09$ & -4.795 .000 & \\
\hline
\end{tabular}

Sumber: Diolah dari Data Primer, 2016 
Tabel 21. Perbandingan Rata-Rata Perubahan Keuntungan Pengrajin Tahu pada Kenaikan Harga Kedelai antara Sistem Pembayaran Sebelum Produksi dan Setelah Produksi

\begin{tabular}{|c|c|c|c|}
\hline Sistem Pembayaran & $\begin{array}{c}\text { Sebelum Produksi } \\
(\%)\end{array}$ & $\begin{array}{c}\text { Setelah Produksi } \\
(\%)\end{array}$ & $\begin{array}{c}\text { Perubahan } \\
(\%)\end{array}$ \\
\hline Penurunan Keutungan (\%) & $-9,46$ & $-22,04$ & $-57,07$ \\
\hline
\end{tabular}

Sumber : Data Primer Diolah, 2016

Kenaikan harga kedelai sebesar 14,28 persen, dengan menggunakan sistem pembayaran sebelum produksi dalam memperoleh bahan baku kedelai pengrajin tahu hanya mengeluarkan biaya sebesar $-9,46$ persen. Sedangkan pengrajin tahu yang menggunakan sistem pembayaran setelah produksi, harus mengeluarkan biaya sebesar -22,04 persen. Selisih biaya bahan baku kedelai antara pengrajin tahu yang menggunakan sistem pembayaran sebelum produksi dan setelah produksi adalah sebesar 12,58 persen. Jadi jika dilihat pada Tabel 21 bahwa pengrajin tahu yang menggunakan sistem pembayaran setelah produksi dalam memperoleh bahan baku kedelai mengalami tambahan biaya sebesar $-12,58$ persen dibandingkan dengan pengrajin yang menggunakan sistem pembayaran sebelum produksi (langsung).

\section{KESIMPULAN DAN SARAN}

\section{Kesimpulan}

Kenaikan harga kedelai mengakibatkan penurunan keuntungan pengrajin tahu baik pada pengrajin yang menggunakan sistem pembayaran sebelum produksi maupun yang menggunakan sistem pembayaran setelah produksi.

\section{Saran}

Sistem pembayaran kedelai sebaiknya dilakukan sebelum produksi, karena keuntungan lebih banyak dibanding sistem pembayaran lainnya. Sebaiknya antara pengrajin dan pemasok kedelai tetap mempertahankan sistem kontrak.

\section{DAFTAR PUSTAKA}

Adrianto. 2004. Budi Daya dan Analisis Usaha Tani Kedelai, Kacang Hijau dan Kacang Panjang. Absolut. Yogyakarta
Aripin, Z., 2014. Analisis Harga Pokok Produksi Tahu-Tempe pada Home Industri Lela Jaya

Manna Bengkulu Selatan. Skripsi. Universitas Bengkulu

Andi, F., 2012. Penawaran Kedelai Dunia dan Permintaan Impor Kedelai Indonesia Serta Kebijakan Perkedelaian Nasional. Skripsi. Institut Pertanian Bogor. Fakultas Ekonomi dan Manajemen. Bogor

Budihastuti, D. 2016. Profil Usaha Selai Nanas “Cap Burung Maleo" UD. Asli Totabunan di Kelurahan Motoboi Kecil Kota Kotamobagu. Skripsi. Perpustakaan Pertanian Unsrat

Dinas Industri dan Perdagangan. 2014. Laporan Kebutuhan Industri Tahu. Sulawesi Utara

Dwi, Y., 2013. Analisis Persediaan Bahan Baku Kedelai di Industri Pengolahan Tempe Samodra Kota Surakarta. Skripsi. Universitas Sebelas Maret Surakarta. Fakultas Pertanian. Agribisnis. Surakarta

Hutagaol, E., 2009. Analisis Tingkat Keuntungan dan Faktor-Faktor Yang Mempengaruhi Keuntungan Usaha Dagang Jeruk Medan di Pasar BSD City Kecamatan Serpong, Kabupaten Tangerang. Jurnal. Fakultas pertanian IPB. Respository. Ipb.ac.id.

Iriana, A., 2014. Analisis Rantai Nilai Tahu Kuning Disentra Industri Tahu Tegal. Skripisi. Universitas Diponegoro Semarang. Tegal

Lasena, K ., 2013. Analisis Keuntungan Pengrajin Tahu. Skripsi. Universitas Gorontalo. Fakultas Pertanian Sosial Ekonomi. Gorontalo 
Melanton, G., 2012. Analisis Biaya Produksi Kertas Brief Card dan Wood Free Studi Kasus di PT. Pindo Deli Pulp dan Paper Karawang, Jawa Barat. Skripsi. Fakultas Kehutanan IPB. StarPdf.com

Pangastuti. 2006. Analisis Dampak Penurunan Subsidi BBM Terhadap Industri Tahu Skala Kecil di Kabupaten Bogor. Skripsi. Institut Pertanian Bogor. Bogor

Patmawaty. 2009. Analisis Dampak Kenaikan Harga Kedelai Terhadap Pendapatan Usaha Pengrajin Tahu Skala Kecil dan Rumah Tangga. Skripsi. Institut Pertanian Bogor

Purnamasari. 2006. Analisis Faktor Faktor yang Mempengaruhi Produksi dan Impor Kedelai di Indonesia. Skripsi. Institut Pertanian Bogor. Bogor

Sarwono, B dan Saragih., 2003. Membuat Aneka Tahu. Penebar Swadaya. Jakarta

Sugiharto. 2001. Teknik sampling. PT Gramedia Pustaka Utama. Jakarta

Suyanto, N., 2000. Ekonomi. Penerbit Erlangga. Jakarta
Sitorus. 1987. Ilmu Usaha Tani. UI Press. Jakarta

Soemarsono, S.R ., 2007. Akutansi Suatu Pengantar. PT Rineka Cipta. Jakarta

Widhyasmoro, I dan Mahastanti, L.A., 2012. Analisis Pengaruh Kebijakan Utang, Profitabilitas, Likuiditas, Kesempatan Investasi, dan Jenis Industri Terhadap Kebijakan Dividen. Jurnal. Fakultas Ekonomi dan Bisnis Universitas Kristen Satya Wacana.

Statistik. Sulut

.2013. Statistik Sulut. Badan Pusat 2015. Statistik Sulut 2015. Badan Pusat Statistik. Sulut

.2014. Disperindag Sulut 2014. Dinas Perindustrian dan Perdagangan.

Sulawesi Utara .2014. Kandungan Gizi Tahu 2014. Direktorat Gizi Depkes RI .2015. Perkembangan Usaha Kecil. Badan Pusat Statistik. Banda Aceh 